\title{
Incumbency Advantage as a Basis of Party Coalition in Regional Heads Candidate Selection
}

\author{
${ }^{1}$ CAROLINE PASKARINA, ${ }^{2}$ RINA HERMAWATI, ${ }^{3}$ NURAENI \\ 1Universitas Padjadjaran, Jalan Bukit Dago Utara No. 25 Bandung, Indonesia, \\ 23Universitas Padjadjaran, Jalan Raya Bandung-Sumedang Km. 21 Jatinangor, Indonesia, \\ email: ${ }^{1}$ caroline.paskarina@unpad.ac.id; 2 rina_hermawati@unpad.ac.id; ${ }^{3}$ nuraeni@unpad.ac.id
}

\begin{abstract}
Studies on the incumbency advantage have proven that incumbents remain strong candidates in the elections. However, these studies focused more on the incumbent figures as the main capital in winning votes. This article analyzes the incumbency advantage from different perspective as the basis for the formation of parties coalitions in local elections. Using a qualitative method, this article compares three regions in West Java, namely City of Cimahi, City of Tasikmalaya, and Regency of Bekasi to show how incumbent use their advantages in influencing the dynamics of candidate selection within political parties, especially in determining who will become their vice mayor/regent and mobilization strategies during the campaign period. Data is collected through in-depth interview with parties' elites who were involved in candidate selection. Although not all incumbents in the three regions won, but the results of this research proved the dominance of incumbent in the formation of party coalitions due to their structural position in the party and their access to public resources. This finding confirms the importance of criticizing the practice of transactional politics in selecting the candidates in a figure-based political era.
\end{abstract}

Keywords: incumbent advantage, candidate selection, local election

\section{Introduction}

This article analyzes whether incumbency advantage is used as basic reasoning for parties to form a coalition in candidate selection for regional head election. In general, party combination is often interpreted the same as party coalition. Political coalitions are defined in two models: government coalitions and legislative coalitions (Ahmad, 2014; Cheibub, Przeworski, \& Saiegh, 2004). The combined practice of political parties that take place in the context of regional head elections is different from the concept of the political coalition because the previous one is not related to the formation of a government or certain policies in the legislature.

The formation of party coalition in regional head elections is a consequence of the enactment of Article 40 (1) of Law No. 8 of 2015 concerning Amendments to Law Number 1 of 2015 concerning Determination of Government Regulations in lieu of Law
Number 1 Year 2014 concerning the Election of Governors, Regents, and Mayors into Laws. This provision sets limits on the requirements for candidate pairs registration through political parties, that is political parties or a coalition of political parties can register pairs of candidates if they have met the requirements of obtaining at least $20 \%$ of the seats of the Regional People's Representative Council or $25 \%$ of the accumulated legal vote in the general election of members of the Regional People's Legislative Council in the area concerned. Referring to the provision, the party coalition is initially formed to meet the requirements in the registration of candidates for regional head candidates.

In a multiparty system in Indonesia, only a small number of parties can submit their own pairs of regional head candidates, so that the formation of a joint party in nomination becomes a necessity in regional head elections. In addition to considering the constellation of political power, the formation

Received: 2018-10-13, Revised: 2019-01-24, Accepted: 2019-05-29 
of a joint party cannot be separated from the emergence of potential figures as candidates for regional heads, especially incumbents who have distinct advantages.

The quality of candidate figures is still a dominant factor in mobilizing supporters' votes in general elections (Shapiro, Miller, \& Shanks, 2006). Likewise, it also happens in the context of regional head election which from the beginning is more centered on the candidate figures. Various criteria set by the party for the candidates are centered on these figures of popularity, electability, and acceptability. The problem is, instead of trying to form these three criteria on their cadres, political parties tend to be pragmatic by looking for figures that already have all the three criteria even though they are not cadres.

In the 2017 concurrent regional head elections, there were 105 incumbent candidates or approximately $31.16 \%$ of all competing candidate pairs (Sukmajati, 2017). This number is indeed decreasing compared to the simultaneous election of regional heads in 2015 , where $82.5 \%$ of candidates who fought were incumbents and $63.2 \%$ of them were reelected (Sukmajati, 2017). The percentage of being re-elected seems to be the motivation for the high inclusion of incumbents in the next election period. The incumbent has a great chance to win the election because of a number of advantages they have (Gordon, S. C. \& Landa, 2009; Stone, 2011).

Studies of incumbency advantage that dominate the literature focus more on the explanation of factors that cause incumbents to be re-elected (Ashworth, Bueno De Mesquita, \& Friedenberg, 2017; Gordon, S. C. \& Landa, 2009; Mayhew, 2008; Trounstine, 2011). The main focus lies in the incumbent itself, both in terms of personal quality and performance (Carson, Engstrom, \& Roberts, 2007; Cox \& Katz, 1996; Iskandar, 2015; Lestari, 2011; Stone, 2011; Sulistiyanto, 2009).

Besides the personal side of incumbents, the incumbency advantage is also analyzed from an institutional perspective which links the incumbency advantage with the institutionalization of parties and electoral systems (Dettman, Pepinsky, \& Pierskalla, 2017), the activities of legislature (Johannes \& McAdams, 1981), changes in electoral districts (Cover, 1977; Erikson, 1972; Lundell, 2004), and the level of decentralization within the party (Lundell, 2004).
The various studies above show that in general, the success or failure of incumbents is determined by many factors (Shomer, 2014; Sukmajati, 2017). Some of them are due to the factor of the level of institutionalization of party systems. This first factor is also related to party identification, where voters who choose certain political parties tend to vote for candidates from those political parties. Second, the level of voter participation. Experience from many countries shows that the high rate of abstinence has a relationship with the re-election of incumbent candidates. Third, a view from the challenger side. Although the candidate is predicted to lose, the ability factor of the challenger to conceptualize him or herself in facing the incumbents' advantage also greatly influences the victory. Fourth, from the prospective of incumbent him or herself. Many cases show that excessive self-confidence among potential incumbents turns out to be an attitude of disdain for the challenger and results in incumbent failure.

However, a number of incumbency advantages above seem to cause new problems. The problem is the pragmatic attitude of most political parties that tend to "play safe". They arereluctant to compete against incumbents. Political parties tend to do their own 'pragmatic' coalitions by ignoring the ideological background of each party and supporting one who is none other than the incumbent, without spawning other candidates from the cadres of each party.

This article analyses the incumbency advantages from a different perspective, that is as the basis for the formation of a parties coalition in the nomination of candidates in simultaneous regional head elections. Using qualitative methods, this article compares three regions in West Java, namely Cimahi City, Tasikmalaya City, and Bekasi Regency to show how incumbents use their advantages to influence the dynamics of candidate selection in political parties, especially when determining the vice pairs.

The stage of candidacy is chosen as the focus in this article because of the strategic value of the power struggling that took place at this stage. Candidate selection is a vulnerable phase with high costs because it involves exchanging resources, especially in the form of capital or money. The competition that is actually formed in the candidate selection phase is competition in terms of providing money to form popularity, as well 
as to obtain support from the party to be nominated (Saputra, 2018).

A number of studies focusing on candidate selection generally establish political parties a unit of analysis because candidate selection is the domain authority of political parties. Practices occurred in Indonesia create different phenomena. Amid the declining capacity of political parties, the emergence of potential figures as candidates is more promoted by institutions other than political parties. Especially with the opening of opportunities for individual candidates to participate in competing in regional elections, figure-based politics and volunteer support actually play a greater role in the promotion of candidates.

Shin (2017) argued that the tendency to strengthen the candidate selection system that focuses on figures is caused by the context of democratic transition, where the system has the most chance of winning candidates. The electoral system and the interrelated party system form the political context behind the strengthening of figurebased politics. According to him, there are 3 factors that determine the choice of the selection system, namely voter demands, political party access to resources, and the electoral system choice in new democracies. This finding is in line with that proposed by Carey \& Shugart (1995), that candidatecentered system selection will be chosen when personal votes are stronger and the party has access to limited resources.

Based on those assumptions, this article is focusing on how the incumbency advantage is optimized as bases to form parties coalition in candidate selection. The aims are: first, to identify the incumbency advantages used in that phase; and second, to analyze the utility of incumbency advantage in determining candidate pairs in parties coalition.

\section{Research Methodology}

This study uses a qualitative approach which aims to obtain in-depth and comprehensive information about how incumbent advantage becomes the basis for the formation of party coalitions in regional head elections candidacy. To answer those problems, this study collected primary data through in-depth interviews with 16 informants, namely the campaign team (success team) and elite parties who have important roles as decision-makers in their internal parties. Those informants located in 3 regions: Cimahi City, Tasikmalaya City, and Bekasi Regency. These regions were selected because they conducted concurrent regional head election in West Java in 2017 and the occurrence of incumbent as a strong candidate for the winner is predicted to be re elected.

In addition to in-depth interviews, data were also collected through non participatory observations when researchers joined party meetings or campaign teams to get a visual impression of the process and interactions between actors at important moments in the selection of candidates. Observation is also an instrument of data triangulation so that the validity of data obtained from interviews can be tested.

The data obtained will then be analyzed based on the categories of data compiled referring to the formulation of the problem, which consists of: (1) the profile of the incumbents and the advantages they have, and (2) the utilization of the superiority in determining candidate pairs. Interpretation of the data obtained is part of the analysis to reveal how the incumbency advantages became the basis for the formation of a party coalition in candidacy for simultaneous regional elections in West Java in 2017. The analysis of the research questions is presented through 2 (two) sections of discussion, first, identification and analysis of sources of incumbency advantages, and second, analysis of strategies used by incumbents in using their advantages to determine candidate pairs in internal party candidate selection phase.

\section{Results And Discussion}

\section{Incumbency Advantages in Three Regions}

Studies of incumbency advantage seeks to reveal what factors create an opportunity for incumbents to be re-elected, which generally explains that incumbents have the opportunity to win elections because they have experience in their previous or existing positions (direct officeholder), higher quality than challengers, and/or have access to the resources needed to mobilize support such as budgets, bureaucracy, etc. (Ashworth et al., 2017; Cox \& Katz, 1996; Spahn, 2011).

On the other side, the conceptualization of incumbency advantage also explains above as the cause of the formation of coalitions 
in government. This perspective seeks to explain the incumbents' effect based on two frameworks of argument. First, the one which emphasizes the reasons why ruling coalition partners might prefer to reshape coalitions; they even have considered coalition size and ideological compatibility. Second, the one which emphasizes procedural excellence that can enhance the ability of the ruling government to reshape the coalition, given the desire of the coalition partners to do so (Martin \& Stevenson, 2010). This concept confirms that the incumbency advantage is also one of the considerations for parties in forming coalitions and determining the candidate pairs.

Political party's consideration in determining which candidates to be supported is always associated with the advantages owned by the candidates. Stone (2011) focuses on the opportunity for incumbent victory in voter preference for the capacity and capability they shown during their tenure (direct advantages of being in office). Stone saw the characteristics of incumbents which related to leadership qualities, such as the character of personal integrity and performance and skills, ability to work with other leaders, understanding the problems, and the ability to solve those problems. In line with Stone, Gordon and Landa (2009) explained the supporting factors of incumbents to win including a number of sources that other candidates do not have. The first source is a good relationship between interest groups and elites in the region, known as the direct officeholder model. Second is the discount campaign. In this model, the incumbent does not need to spend a lot of money to get him elected again in the election and it shows the big names the incumbent has. Whereas, the third model is a district partisan bias, namely the tendency of incumbent supporting bases over certain areas resulting from incumbent performance and the proximity of incumbents to elites within a particular domain.

Incumbency advantage is often associated with political dynasty, when incumbent figures come from families or clans that have a long history of political power (Fiva \& Smith, 2018). Incumbent candidates can obtain benefit because of their familial relationships with figures who have or are in power, which are called inherited incumbency advantages (Smith \& Martin, 2017) or dynasty advantages (Feinstein, 2010).

Various concepts above show that incumbency advantage has a variety of sources, both from the figure itself and from outside the figure. The discussion in this section will outline the sources of incumbency advantage in the 3 regions of study location, namely Cimahi City, Tasikmalaya City, and Bekasi Regency.

\section{Cimahi City}

The figure of the incumbent who competed in the 2017 Cimahi Mayor Election was Atty Suharti, mayor of the previous period. She was the wife of the Cimahi former mayor Itoc Tochija. In the period of 2012-2017, Atty Suharti was nominated by Partai Persatuan Pembangunan (United Development Party or PPP), Golkar Party, Partai Kebangkitan Bangsa (National Awakening Party or PKB), and Partai Bulan Bintang (Crescent Star Party or PBB). The deputy mayor in the first period was a politician from Golkar Party, while Atty herself was a PPP cadre at that time. In the 2017 nomination period, Atty switched the party to Golkar and her partner was a politician from Partai Keadilan Sejahtera or Prosperous Justice Party (Achmad Zulkarnain). The pair is supported by Golkar, PKS, and Nasdem.

Changes in the configuration of the supporting party and the choice of partners from different parties are thought to be the result of the failure of Tochija family to seize a number of important political positions in the 2014 legislative elections. Itoc Tochija (Atty Suharti's husband and former Cimahi Mayor in 2007-2012) was not re-elected from PPP, while their two children also failed to win seats in the West Java House of Representative and Cimahi City House of Representative. This caused Itoc Tochija and all his family members quit the PPP and went to Golkar Party., Itoc nominated his wife as mayor of Cimahi in the 2017 regional head elections when he was a Chairman of the Golkar Party in Cimahi. This strategic role of him showed that opportunities for incumbent advantage can be constructed by political actors outside the incumbent.

\section{Tasikmalaya City}

In the election of Mayor of Tasikmalaya, there were 2 incumbents who competed for the position, namely Budi Budiman (incumbent mayor of the previous period) and Dede Sudrajat (incumbent deputy mayor of the previous period). Both of them run in pairs with other figures. Interestingly, the two incumbents also have links to the leading 
bus companies in Tasikmalaya City. In the previous period, Budi Budiman received full support from Mayasari Group, but in the simultaneous regional elections in 2017, Mayasari Group shifted support to Asep Hidayat. Asep Hidayat is a pediatrician who happens to be the son-in-law of Mayasari Group family and officials at Mayasari Care Foundation. Meanwhile, Budi Budiman was a businessman who began his career in public transportation business, and was also a continuing trader believable to hold a Suzuki dealer in Tasikmalaya until he was trusted to hold control of several companies under the Mayasari Group (http://jurnalpriangan. com/2016/10/06 / this is the profile of businessmen-bus-going-forward-pilkada /, accessed on 31 July 2017). The companies experienced significant development. Budi Budiman became a well known successful entrepreneur and his businesses developed into sectors of various automotive, property, and construction.

Budi Budiman is also active in various professional, social, and religious organizations, including the Organisasi Angkutan Darat (Organda) or the land transportation organization in Tasikmalaya, the Sharia Economic Community (Masyarakat Ekonomi Syariah or MES), the Badan Amil Zakat (BAZ or Amil Zakat Agency) in Tasikmalaya, the Tasikmalaya Regency Great Mosque Construction Committee, and so on. Budi Budiman also works in the field of education by becoming a chairman in of two institutions of Bojong Islamic Foundation which manages several formal and informal institutions, and the Tasikmalaya Educational Institution (LP3I) which has developed rapidly and become one of the most popular educational institutions in the community. He was awarded the best Indonesian Educational Institution's (LP3I) manager in 2010. In the religious field, Budi Budiman also established the Attiyah Mosque and completed the project development of various places that became the icons and landmarks of Tasikmalaya city, such as the Great Mosque of Tasikmalaya, Cikurubuk Market, Bale Kota, and Mayasari Plaza.

Budi Budiman began his political career as a manager of the Tasikmalaya City branch Representative Council of PPP, then a chairperson of the PPP's branch Representative Council of Tasikmalaya in 2010-2015. In the 2007 regional election, Budi became a candidate for mayor pairing with Dr. Wahyu Sumawijaya from the Democrat Party for Deputy Mayor but they lost; and in the 2011 Regional Election, Budi paired up with an entrepreneur, Dede Sudrajat, and won the election defeating the incumbent Syarief Hidayat at that time.

\section{Bekasi Regency}

Neneng Hasanah Yasin was the incumbent of Bekasi Regent in the previous period. In the 2017 Bekasi Regent Election, she was pairing with Eka Supria Atmaja, a Chairperson of Bekasi District Representative Council, to compete for the regent position. Neneng Hasanah Yasin's political career began in Kosgoro, a community organization affiliated with Golkar Party. Neneng Hasanah once served as a Chairman of the 1957 Kosgoro in Bekasi Regency, treasurer of the Golkar DPD in West Java Province, treasurer of National Committee of Sport in Bekasi District, and West Java Provincial Local

Table 1

Incumbency Advantages in Three Regions

\begin{tabular}{|c|c|c|c|}
\hline Region & Dynasty Advantage & Party Advantage & Other Resources \\
\hline Cimahi City & Wife of former mayor & $\begin{array}{l}\text { Gain support through } \\
\text { candidacy promoted } \\
\text { by her husband as } \\
\text { Chairman of Golkar } \\
\text { Party in Cimahi }\end{array}$ & $\begin{array}{l}\text { Bureaucracy, social } \\
\text { network }\end{array}$ \\
\hline Tasikmalaya City & None & $\begin{array}{l}\text { Structural position in } \\
\text { PPP (Chairman of PPP } \\
\text { Branch Representative } \\
\text { Council in Tasikmalaya) }\end{array}$ & $\begin{array}{l}\text { Bureaucracy, social } \\
\text { network, business } \\
\text { enterprise }\end{array}$ \\
\hline Bekasi Regency & $\begin{array}{l}\text { Daughter of a local } \\
\text { businessman in Bekasi }\end{array}$ & $\begin{array}{l}\text { Structural position in } \\
\text { Golkar }\end{array}$ & $\begin{array}{l}\text { Bureaucracy, social } \\
\text { network, business } \\
\text { enterprise }\end{array}$ \\
\hline
\end{tabular}


Parliament Members for the 2009-2014 period. Her family background is also quite supportive in shaping the modality of Neneng Hasanah in the political sphere. Neneng Hasanah's parents are one of the leading entrepreneurs in Bekasi Regency engaged in rice business (https://gobekasi.pojoksatu. id/2015/10/10/orangtua-bupati-nenenghasanah-yasin-dijuluki-ratu-proyek- thisreason/, accessed in October 10, 2018).

The incumbents in the regional head elections in Cimahi City, Tasikmalaya City, and Bekasi Regency have similarities, namely the family background of the incumbents which is not only strengthening their political capitals but also economic capital because of access to resources in their respective regions. In addition to access to economic resources through relationships with entrepreneurs, incumbents also have advantages in terms of access to public resources as a consequence of their position as incumbents. These public resources become capitals to maintain support from the people while strengthening patronistic relations with the party they lead.

As shown in Tabel 1 , the three research locations showed similar findings in terms of sources of power which became the superiority of incumbents, namely the closeness to the previous ruling figure, which turned out to still have a kinship relationship. This confirms that dynastic and kinship relations are an important source in shaping the superiority of incumbents (Aspinall \& As'ad, 2016; Feinstein, 2010; Fiva \& Smith, 2018). This relationship becomes the initial capital for incumbents to enter the political arena and enlarge its superiority by controlling economic resources. The achievements of incumbents in government in the previous period gave formal legitimacy to the success of incumbents in the public eye. This is the basis to strengthen the bargaining position of incumbents in internal party candidate selection (Paskarina, Hermawati, \& Yunita, 2019); a political bargaining position that is basically built on kinship politics and mastery of patronistic resources (Gherghina \& Volintiru, 2017; Manor, 2013).

\section{Utilizing Incumbents Advantages in Determining Vice Regional Head}

The discussion in this section will analyze how incumbents optimized their advantages to influence the party's internal candidacy process, especially in determining the vice regional head. Rahat and Hazan (2010; 2001; 2007) divided the candidate selection process into two (2) dimensions, namely selectorate and candidacy. Selectorate is the body that selects candidates. According to Best and Costa (Hazan \& Rahat, 2010), selectorate is an important intermediary actor in the recruitment process. Selectorate can consist of one person, several, or many people. The range starts from the inclusive to the exclusive, which determines how democratic the party is in determining the candidates it supports (Hazan \& Rahat, 2010).

The second dimension is candidacy. Basically, candidacy is a discussion of who can submit his or her candidacy in the process of selecting candidates to be carried out by the party (Hazan \& Rahat, 2010). The political process takes place in this dimension explains who can determine the candidate criteria, both in terms of capacity and personal characters. The power relations in this dimension also cover a fairly wide range from those of an inclusive manner to those of exclusive one (Hazan \& Rahat, 2010).

Selection of candidates, thus, becomes an arena of power in which the parties, both candidates and political parties fight for their interests. The discussion in this section will show how incumbents use their advantages as a bargaining position in both dimensions of candidate selection.

\section{Cimahi City}

In an interview with the Chair of the Joint Team of Candidates for Atty and Azul, the supporting party coalition has been explored since the beginning of the candidacy period. As an incumbent party, Golkar was in a position to benefit from Atty's incumbency advantage, both in her position as an incumbent and her close relationship with Itoc Tochija as the former mayor of Cimahi in the previous period. In the early days of candidacy, efforts to win candidates were focused on the selection of candidates for deputy mayor who could strengthen the superiority of incumbents but would not exceed the incumbent's figure.

From the interviews with Golkar Party structural, it was revealed that the figure of Itoc Tochija was instrumental in determining the deputy of mayor candidates. Azul was finally chosen as deputy candidate with a number of considerations. He was once an expert staff member in Cimahi City Government, had a 
good academic background and a track record in various community organizations that were strong enough to foster a supporting base. Determination of pairs of representative candidates then underlies the formation of a coalition of supporting parties.

In the 2017 elections, 3 coalitions were formed:the coalition of Golkar, Nasdem, and PKS carry the pair of Atty Suharti and Achmad Zulkarnain; the Democratic party and Gerindra coalitions that carry Asep Hadad and Irma Indriyani; the coalition of PKB, PPP, Hanura, PAN, and PDIP carry the pair of Ajay Priatna and Ngatiyana. Those candidate pairs came from different backgrounds, namely bureaucrats, politicians, academicians, businessmen, and retired army officials.

\section{Tasikmalaya City}

The emergence of 2 incumbents who fought as a rival made the 2017 Tasikmalaya regional head election a very interesting political event. The party coalition supporting the two incumbents also had relatively balanced strengths. The superiority of the defense of Mayor Budi Budiman, aside from his position as incumbent, was more popular in the eyes of the public, as well as support from PPP as the dominant party in Tasikmalaya city. The two incumbent candidates also fought for PPP support since they emerged from the same party, that is PPP. Budi was known to be in PPP's Romi and Dede in Djan Farid's PPP.

In the end, the PPP decided to promote Budi Budiman as the candidate for mayor. The decision was the result of the Branch Leadership Meeting (Rapat Pimpinan Cabang) of the party. The support was given to Budi Budiman who also served as Chair of the PPP's Branch Representative Council. This finding emphasizes that the incumbency advantage is not only shaped by the performance in government, but also by political position in the party.

\section{Bekasi Regency}

In an interview with the Golkar Party Deputy Secretary for Legal Affairs of the Regional Representative Council of West Java, it was stated that the candidacy process was carried out democratically with a reference to the party's regulations, in which candidacy was prioritized for party cadres. This is what underlies the decision to carry Neneng Yasin and Eka Suria Atmaja, both of which are cadres of the Golkar Party. In terms of determining the pair to be carried out, either in the position of regent or deputy regent, the informant explained that the main consideration was the popularity of figures tested through surveys. In the survey, names that have been determined as partners compared to the level of popularity. For example, if A becomes regent and $B$ as his vice/deputy, is his popularity higher than if $B$ is positioned as regent and $A$ as his vice/deputy? The final decision regarding the position of the candidate is determined by the results of the survey. The informant provided an interesting illustration of the 2004 Presidential Election case, in which the figure popularity was not always in sync with the popularity of the couple. The informant told that: "... during the 2004 presidential election, the survey results showed that Megawati was the most popular for president because she had previously served as president. While the most popular position for vice president is Hasyim Muzadi. But, when surveyed as a couple, both were defeated by the popularity of SBY-JK (Susilo Bambang Yudhoyono and Jusuf Kalla). This means that popularity as an individual is different when paired with other people ... "

Although popularity is an important factor, electability also influences the candidacy. Electability is generally seen from the track record or performance in the government. The political contract between the Golkar Party and the cadres to be promoted as the Bekasi Regent candidate is related to a number of things, including the use of a more optimal Anggaran Pendapatan dan Belanja Daerah (regional income and expenditure budget) to improve the quality of human resources, especially in the health sector (https: //news.okezone. com / read / 2016/07/28/338/1448843 / golkar-restuineneng-hasanah-maju-pilkada-bekasi). The points underlying this recommendation confirm the interests of political parties to maintain their electability because candidates are the representations of political parties. This shows that the dynamics of candidacy are not merely a matter of figure-based politics, but also lead to the efforts of political parties to maintain their survival by obtaining the benefits of electability from the figures they carry.

In the 3 cases above, the incumbent uses his or her structural position in the party as the main capital to determine the figure who will be his or her deputy. This finding reaffirms the centralistic and elitist character 
of the candidate selection system that takes place internally within the party (Aragon, 2013; Close, Kelbel, \& Kern, 2015; Hazan \& Rahat, 2010; Williams \& Paun, 2011). Although incumbents as party elites play a major role in determining their vice pairs, the popularity, electability, and capabilities of the figures of their partners are also being considered. In the Cimahi case, the advantage of the vice-mayor candidate was one of the factors that caused the couple to still get a vote even though the incumbent figure was arrested by the Corruption Eradication Commission.

\section{Conclusions}

This article confirms that the dynastic politics and kinship relations of candidate(s) are an important source in shaping the incumbency advantage. The performance of incumbents in the previous period of officeholder gave formal legitimacy to the success of incumbents in the public eye, which later became the basis for strengthening the bargaining position of incumbents in the selection of internal party candidates. The incumbency advantage in the three regions shows that the bargaining position of incumbent candidates is basically built on the politics of kinship and mastery of patronistic resources. The dominant role of candidate figures, especially incumbents, in the candidacy process has caused the internal party's selection mechanism to be centralized and elitist. Incumbents who hold structural positions in party organization are decisive in making decisions regarding who will pair up with him or her. This role is the implication of incumbency advantage that comes from access to resources, both in the form of public resources and networks with private sectors which shape the economic modalities of incumbent candidates. Access to these resources is used as the capital by incumbents to maintain patronage relations with the party.

The direct method to elect the regional head has led the candidate selection system to become candidate-centered. The regulation that directs a party to form a coalition in order to nominate candidates in regional head elections does not encourage parties to form a permanent or based on ideological similarities coalition. Consideration in forming a party coalition is based more on the calculation of a number of seats in the parliament which indicates the constellation of political power in the region and the popularity of the figure to be paired. This conclusion confirms the importance of criticizing the practice of transactional politics in candidate selection in the era of figure-based politics. Selection of candidates centered on figures should direct the party to better prepare its cadres to have high electability, which in turn will strengthen the party's bargaining position when carrying out candidate pairs in regional head elections.

\section{Acknowledgement}

The author would like to thank Universitas Padjadjaran for funding this research, through Fundamental Research Scheme, as part of Unpad Internal Grants for Research inn 20172018.

\section{References}

Ahmad Malik, F., \& Ahmad Malik, B. (2014). Politics of Coalition in India (Vol. 2). Online. Retrieved from http://jppgnet. com/journals/jppg/Vol_2_No_1_ March_2014/1.pdf

Aragon, F. (2013). Political Parties, Candidate Selection, and Quality of Government. The BE Journal of Economic Analysis \& Policy, 13(2), 783-810. https://doi.org/10.1515/ bejeap-2013-0036

Ashworth, S., Bueno De Mesquita, E., \& Friedenberg, A. (2017). On the Incumbency Advantage *. Retrieved from https://www. iq.harvard.edu/files/iqss-harvard/files/ advantage-incumbency-2017-04-07.pdf

Aspinall, E., \&As'ad, M. U. (2016). Understanding family politics: Successes and failures of political dynasties in regional Indonesia. South East Asia Research. https://doi. org/10.1177/0967828X16659571

Carey, J. M., \& Shugart, M. S. (1995). Incentives to cultivate a personal vote: A rank ordering ofelectoral formulas. Electoral Studies, 14(4), 417-439.

Carson, J. L., Engstrom, E. J., \& Roberts, J. M. (2007). Candidate quality, the personal vote, and the incumbency advantage in congress. American Political Science Review, 101(2), 289-301. https://doi. org/10.1017.S0003055407070311

Cheibub, J. A., Przeworski, A., \& Saiegh, S. M. (2004). Government coalitions and legislative success under presidentialism and parliamentarism. British Journal of Political Science. https://doi.org/10.1017/ S0007123404000195

Close, C., Kelbel, C., \& Kern, A. (2015). Party crashers? How Belgian citizens view 
CAROLINE PASKARINA, et al. Incumbency Advantage as a Basis of Party Coalition in Regional Heads Candi...

democratic innovations within and beyond political parties (pp. 1-27).

Cover, A. D. (1977). One Good Term Deserves Another: The Advantage of Incumbency in Congressional Elections. American Journal of Political Science. https://doi. org/10.2307/2110580

Cox, G. W., \& Katz, J. N. (1996). Why Did the Incumbency Advantage in U.S. House Elections Grow? American Journal of Political Science. https://doi. org/10.2307/2111633

Dettman, S., Pepinsky, T. B., \& Pierskalla, J. H. (2017). Incumbency advantage and candidate characteristics in open-list proportional representation systems: Evidence from Indonesia. Electoral Studies, 48, 111-120. https://doi.org/10.1016/j. electstud.2017.06.002

Erikson, R. S. (1972). Malapportionment, Gerrymandering, and Party Fortunes in Congressional Elections. American Political Science Review. https://doi. org/10.2307/1957176

Feinstein, B. D. (2010). The dynasty advantage: Family ties in congressional elections. Legislative Studies Quarterly. https://doi. org/10.3162/036298010793322366

Fiva, J. H., \& Smith, D. M. (2018). Political Dynasties and the Incumbency Advantage in Party-Centered Environments. American Political Science Review, 112(03), 706-712. https://doi.org/10.1017/ s0003055418000047

Gherghina, S., \& Volintiru, C. (2017). A new model of clientelism: Political parties, public resources, and private contributors. European Political Science Review, 9(1), 115-137. https://doi.org/10.1017/ S1755773915000326

Gordon, S. C. \& Landa, D. (2009). Do The Advanteges Of Incumbency, Advantage Incumbent? The Journal of Politics, 71(4), 1481-1498.

Hazan, R. Y., \& Rahat, G. (2010). Democracy within Parties. Oxford: Oxford University Press.

Johannes, J. R., \& McAdams, J. C. (1981). The Congressional Incumbency Effect: Is It Casework, Policy Compatibility, or Something Else? An Examination of the 1978 Election. American Journal of Political Science. https://doi. org/10.2307/2110817

Lundell, K. (2004). Determinants of Candidate Selection: The Degree of Centralization in Comparative Perspective. Party Politics, 10(1), 25-47. https://doi. org/10.1177/1354068804039119
Manor, J. (2013). Post-clientelist Initiatives. In K. Stokke \& O. Tornquist (Eds.), Democratization in the Global South: The Importance of Transformative Politics (pp. 243-254). New York, USA: Palgrave Macmillan.

Martin, L. W., \& Stevenson, R. T. (2010). The conditional impact of incumbency on government formation. American Political Science Review, 104(3), 503-518. https:// doi.org/10.1017/S0003055410000213

Mayhew, D. R. (2008). Incumbency advantage in U.S. presidential elections: The historical record. Political Science Quarterly, 123(2), 201-228. https://doi.org/10.1002/ j.1538-165X.2008.tb00622.x

Paskarina, C., Hermawati, R., \& Yunita, D. (2019). Combining Clientelism and Incumbency Advantage : Political Strategy in Candidate Selection for the 2017 Local Head Election in Bekasi Regency. Politik Indonesia: Indonesian Political Science Review, 4(January), 21-41.

Rahat, G., \& Hazan, R. Y. (2001). Candidate Selection Methods: An Analytical Framework. Party Politics, 7(3), 297-322.

Rahat, Gideon. (2007). Candidate Selection: The Choice Before the Choice. Journal of Democracy, 18(1), 157-170. https://doi. org/10.1353/jod.2007.0014

Saputra, M. B. (2018). Politics in Indonesia: It's Business As Usual. Retrieved May 26, 2018, from https://thediplomat. com/2018/01/politics-in-indonesia-itsbusiness-as-usual/

Shapiro, R. Y., Miller, W. E., \& Shanks, J. M. (2006). The New American Voter. Political Science Quarterly. https://doi. org/10.2307/2657948

Shin, J. H. (2017). The choice of candidate-centered electoral systems in new democracies. Party Politics, 23(2), 160-171. https://doi. org/10.1177/1354068815581539

Shomer, Y. (2014). What affects candidate selection processes? A cross-national examination. Party Politics, 20(4), 533-546. https://doi. org/10.1177/1354068811436060

Smith, D. M., \& Martin, S. (2017). Political Dynasties and the Selection of Cabinet Ministers. Legislative Studies Quarterly. https://doi.org/10.1111/lsq.12146

Spahn, B. T. (2011). Toward a Fuller Understanding of the Incumbency Advantage in State Legislative Elections: A Quasi-Experimental Approach. Wesleyan University.

Stone, W. J. (2011). Incumbency Reconsidered: 
Prospects, Strategic Retirement, and Incumbent Quality in U.S. House Elections. The Journal of Politics, 72(1), 178-190.

Sukmajati, M. (2017). Calon Petahana. Surat Kabar Kedaulatan Rakyat.

Sulistiyanto, P. (2009). Pilkada in Bantul District: Incumbent, Populism and Decline of Royal Power. In M. Erb \& P. Sulistiyanto (Eds.), Deepening Democracy in
Indonesia: Direct Election for Local Leader (Pilkada) (pp. 190-210). Singapore: ISEAS Publishing.

Trounstine, J. (2011). Incumbency and Responsiveness in Local Elections, 1-38.

Williams, R., \& Paun, A. (2011). What works in candidate selection? Party Conferences, (October). 